Article

\title{
Chiral Amphiphilic Secondary Amine-Porphyrin Hybrids for Aqueous Organocatalysis
}

\author{
Aitor Arlegui ${ }^{1}$, Pol Torres ${ }^{1}$, Victor Cuesta ${ }^{1}$, Joaquim Crusats ${ }^{1,2, *(\mathbb{D})}$ and Albert Moyano ${ }^{1, *}$ (i) \\ 1 Section of Organic Chemistry, Department of Inorganic and Organic Chemistry, University of Barcelona, \\ Faculty of Chemistry, C. de Martí i Franquès 1-11, 08028 Barcelona, Spain; aitorarlegui@hotmail.com (A.A.); \\ torres.yeste.pol@gmail.com (P.T.); v.cuesta@ub.edu (V.C.) \\ 2 Institute of Cosmos Science, C. de Martí i Franquès 1-11, 08028 Barcelona, Spain \\ * Correspondence: j.crusats@ub.edu (J.C.); amoyano@ub.edu (A.M.); Tel.: +34-93-4020818 (J.C.); \\ +34-93-4021245 (A.M.)
}

Academic Editor: Ciril Jimeno

Received: 14 July 2020; Accepted: 24 July 2020; Published: 28 July 2020

check for updates

\begin{abstract}
Two chiral proline-derived amphiphilic 5-substituted-10,15,20-tris(4-sulfonatophenyl) porphyrins were prepared, and their $\mathrm{pH}$-dependent supramolecular behavior was studied. In neutral aqueous solutions, the free-base form of the hybrids is highly soluble, allowing enamine-based organocatalysis to take place, whereas under acidic conditions, the porphyrinic protonated core of the hybrid leads to the formation of self-assembled structures, so that the hybrids flocculate and their catalytic activity is fully suppressed. The low degree of chirality transfer observed for aqueous Michael and aldol reactions strongly suggests that these reactions take place under true "in water" organocatalytic conditions. The highly insoluble catalyst aggregates can easily be separated from the reaction products by centrifugation of the acidic reaction mixtures, and after neutralization and desalting, the sodium salts of the sulfonated amine-porphyrin hybrids, retaining their full catalytic activity, can be recovered in high yield.
\end{abstract}

Keywords: J-aggregates; aqueous organocatalysis; porphyrins; switchable catalysis; aldol reaction; Michael reaction

\section{Introduction}

Catalysis is a key concept in contemporary chemistry, with far-reaching implications in several fields ranging from molecular biology to the sustainable large-scale synthesis of drugs, agrochemicals, or functional materials. While, in the past four decades, impressive advances with regard to catalytic efficiency and enantioselectivity have been achieved, we are still far from the exquisite degree of sophistication exhibited by multienzymatic catalytic systems. Actual catalytic processes in live organisms usually take place in parallel, and the required spatial and temporal control of catalytic activity often entails its modulation by a variety of external factors. It is thus now widely recognized that the introduction of stimuli-responsive behavior in artificial catalysts ("switchable catalysis") is a key factor for the development of more efficient nature-inspired catalytic systems [1]. The modulation of catalytic activity or selectivity by the formation of self-assembled of supramolecular systems has been studied by several research groups in the past two decades [2-6], but the use of aggregation/dissociation processes for the reversible switching of catalytic activity has remained relatively unexplored [7-10]. Amphiphilic meso-(4-sulfonatophenyl)porphyrins constitute one of the simplest systems whose aggregation state can be controlled by means of an external stimulus. In aqueous solutions at acidic $\mathrm{pH}$, typically at values below 4.8 , the diprotonation of the central pyrroleninic core induces the formation of the so-called J-aggregates [11], stabilized by ion-pair contacts between the cationic porphyrin centers and the anionic sulfonate groups of the periphery. In the context of our research program on the 
use of amphiphilic porphyrins and their J-aggregates in aqueous organocatalysis [12,13], we recently found that by covalently binding a cyclic secondary amine with a 4-sulfonatophenylporphyrin scaffold we could modulate the organocatalytic properties of the hybrid structures $\mathbf{1}$ and $\mathbf{2}$ in aqueous aminocatalytic reactions that can take place through enamine intermediates (Scheme 1). In particular, we showed that the catalytic activity of the cyclic secondary amine moieties of the functionalized porphyrins $\mathbf{1}$ and $\mathbf{2}$ is indirectly regulated by varying the $\mathrm{pH}$ value of the medium, which controls the aggregation/deaggregation state of the porphyrin scaffold. In this way, the porphyrin can be rendered inactive at a $\mathrm{pH}$ value in which the cyclic amine unit would otherwise be catalytically active [14].
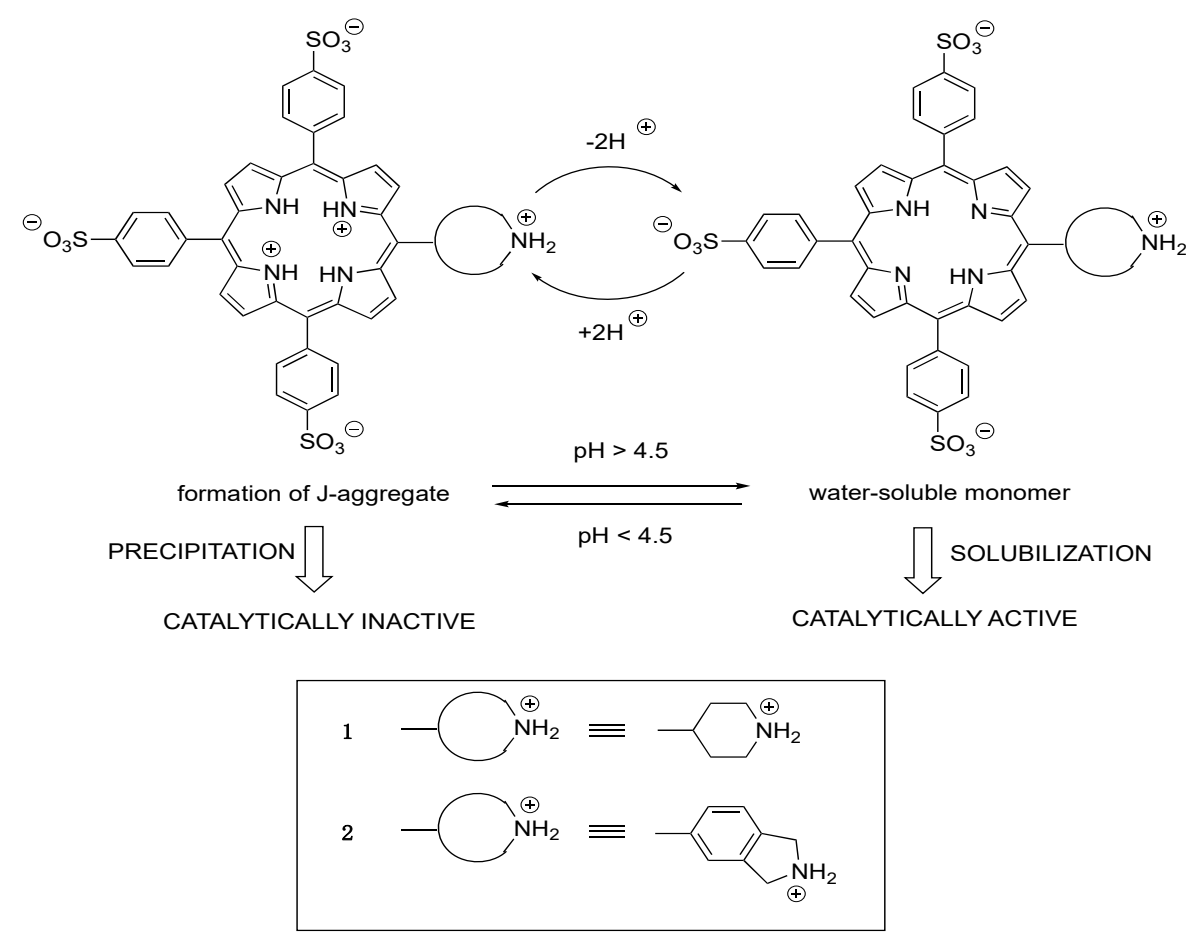

Scheme 1. pH-switchable aminocatalysts based on in situ aggregation/dissociation of amphiphilic porphyrins.

These amine-porphyrin hybrids can readily be prepared, albeit in relatively low overall yields, by a mixed-porphyrin synthesis [15] from pyrrole, benzaldehyde, and a suitable N-Boc-protected aminoaldehyde, followed by treatment of the intermediate mono-functionalized porphyrins (obtained from the statistical porphyrin mixture by chromatographic purification) with hot concentrated sulfuric acid [14]. After some experiments, we were pleased to find that the catalytic activity of the pyrrolidine moiety in the amphiphilic isoindoline-porphyrin hybrid $\mathbf{2}$ for the aldol reaction of cyclohexanone with 4-nitrobenzaldehyde could be selectively and reversibly switched on and off by adjusting the homogeneity of its solutions through $\mathrm{pH}$ variations [14]. To the best of our knowledge, these results constitute the first example in organocatalysis in which the activity of a catalyst can be conveniently regulated in a reversible way by modulating its aggregation state as a response to $\mathrm{pH}$ variations of the media.

Since the pioneering work of Barbas III [16], it is widely recognized that the enantioselectivity of aminocatalytic processes mediated by water-soluble catalysts (such as non-hydrophobic $\alpha$-amino acids) is strongly diminished in aqueous solution, probably due to the disruption of the hydrogen-bond network necessary to organize the transition state, and this is the reason why the use of organocatalysts containing relatively large hydrophobic moieties is generally mandatory in order to preserve the enantiomeric excesses of the products achieved in non-aqueous solvents [17-19]. In fact, aqueous aminocatalytic reactions may actually be taking place by mechanisms other than homogeneous "in 
water" enamine activation (i.e., by general base catalysis with low molecular weight amines, or by micellar catalysis through "on water" processes) $[20,21]$. We thought that it would be interesting to introduce chirality in our amphiphilic secondary amine-porphyrin hybrids, in order to evaluate the degree of asymmetric induction that could be achieved in aqueous organocatalytic aldol and Michael reactions.

\section{Results and Discussion}

When we tried to obtain the 5-(N-Boc-2-(S)-pyrrolidinyl)-10,15,20-triphenylporphyrin 3 by the mixed condensation of readily available [22-24] N-Boc-(S)-prolinal 4 with benzaldehyde and pyrrole, we found that even after careful chromatographic purification of the crude reaction mixture, the desired compound was always obtained together with the corresponding "N-confused porphyrin" [25] 5 (Scheme 2).

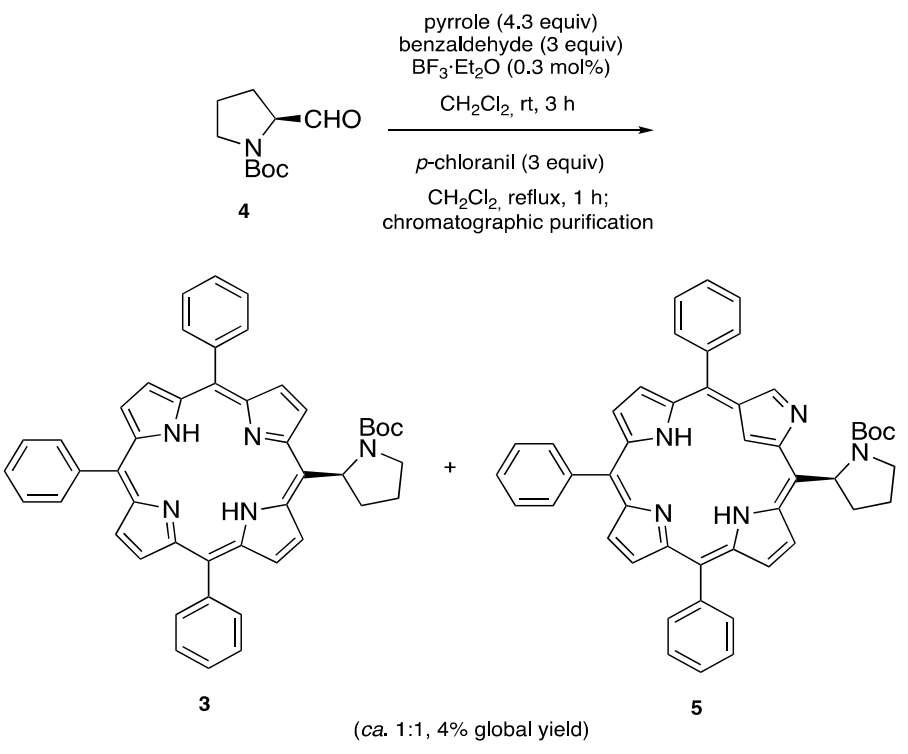

Scheme 2. Attempted preparation of 5-(N-Boc-2-(S)-pyrrolidinyl)-10,15,20-triphenylporphyrin 3.

We hypothesized that the competing formation of 5 was due to a destabilizing steric interaction between the pyrrole rings and the N-Boc-pyrrolidine moiety, and we replaced 4 by the known [26] $N$-Boc-(S)-homoprolinal 6 in the mixed porphyrin synthesis. To our satisfaction, no trace of " $N$-confused porphyrin" was detected, and only the "normal" porphyrin 7 was formed (along with the other expected "normal" porphyrins with a different meso-substitution pattern), and could be isolated in a satisfactory $10 \%$ yield ( $24 \%$ of the statistical theoretical yield) upon chromatographic purification. The sulfonation/deprotection of this compound proceeded without problems, and after the usual isolation/purification procedure, the disodium salt of the amphiphilic pyrrolidine-porphyrin hybrid 8 was obtained in an $82 \%$ yield (Scheme 3 ).

With the aim of introducing a longer spacer between the pyrrolidine and the porphyrin moieties, we synthesized the $N$-Boc-protected bicyclic aldehyde $\mathbf{1 1}$ by direct reductive amination [27] between 4-(hydroxymethyl)piperidine 9 [28] and N-Boc-(S)-prolinal 4, followed by Swern oxidation of the intermediate alcohol 10 (Scheme 4).

This aldehyde was then submitted to the mixed porphyrin synthesis under Lindsey's conditions, affording 12 in a 4\% yield; finally, the sulfonation/neutralization/purification sequence gave access to the chiral amphiphilic porphyrin hybrid 13 in a 58\% yield (Scheme 5). 


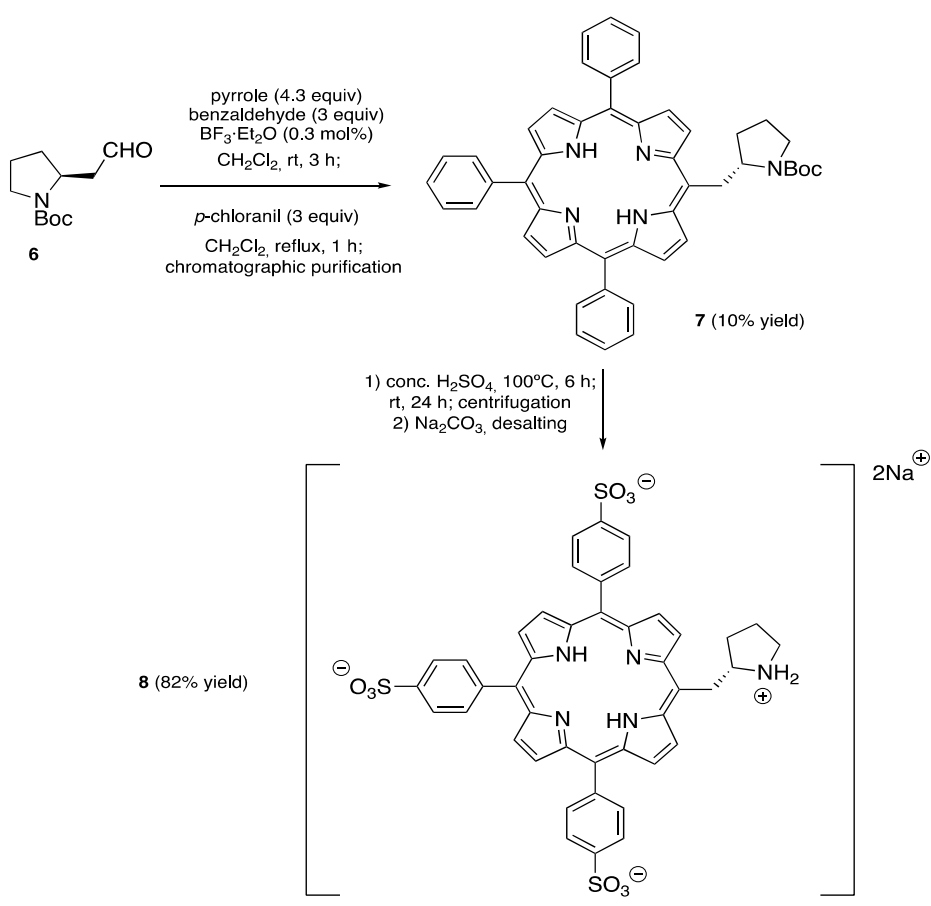

Scheme 3. Preparation of the (S)-5-[(pyrrolidin-1-ium-2-yl)methyl]-10,15,20-tris(4-sulfonatophenyl) porphyrin disodium salt 8 .<smiles>O=CC1CCCN1C(=O)O</smiles>

4

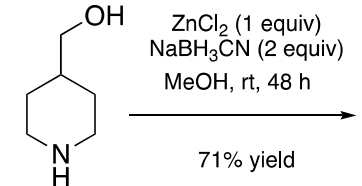

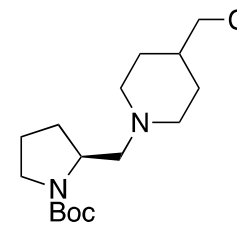

10

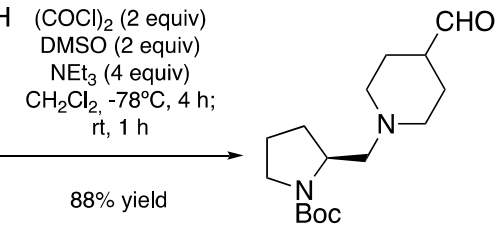

Scheme 4. Synthesis of N-Boc-(S)-2-[(4-formylpiperidin-1-yl)methyl]pyrrolidine 11.

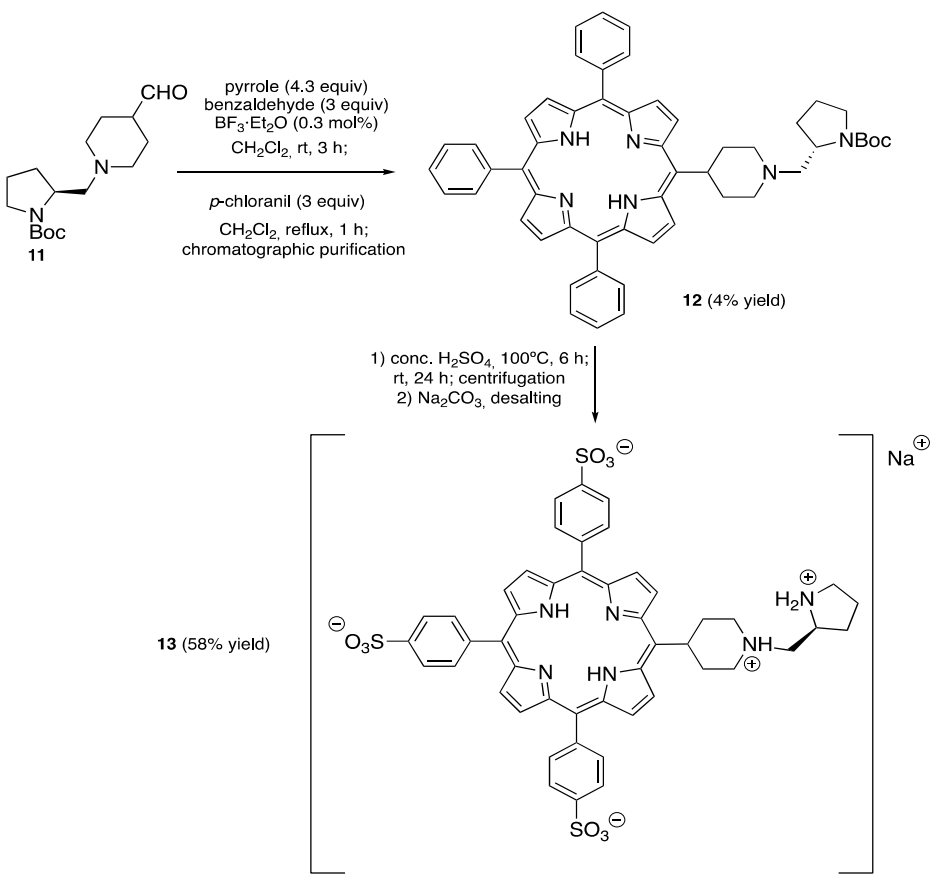

Scheme 5. Preparation of (S)-5-[1-(pyrrolidin-1-ium-2-ylmethyl)piperidin-1-ium-4-yl]-10,15,20-tris(4sulfonatophenyl)porphyrin sodium salt 13. 
As a previous step to ascertain the influence of the aggregation state in the organocatalytic activity of amphiphilic porphyrin hybrids 8 and 13, we determined their inner core $\mathrm{pK}_{\mathrm{a}}$ values by spectrophotometric procedures [29-31]. Since the first protonation of the porphyrin inner core facilitates the entrance of a second proton, the basicity of both pyrroleninic nitrogen atoms are often very similar, so that only the porphyrin $\left(\mathrm{pK}_{\mathrm{a} 1}+\mathrm{pK}_{\mathrm{a} 2}\right) / 2$ mean value can be measured experimentally. The $\mathrm{pK}_{\mathrm{a}}$ value of the porphyrin core of 8 was found to be 3.97, and therefore this compound is ca. 4 times more acidic than $1\left(\mathrm{pK}_{\mathrm{a}}=4.56\right)$ [14], a fact that is probably due to the greater proximity of the positively charged nitrogen atom in the 2-methylpyrrolidinium group than in the piperidinium one. On the other hand, the $\mathrm{pK}_{\mathrm{a}}$ value for $\mathbf{1 3}$ was 4.39 , only marginally lower than that of 1 , suggesting that the presence of the additional protonated pyrrolidine moiety exerts only a small destabilizing effect on the diprotonated porphyrin core beyond that of the piperidinium. It should be noted, however, that the $\mathrm{pK}_{\mathrm{a}}$ obtained for $\mathbf{1 3}$ is only approximate, since for this compound, in the buffered solutions in which the spectra were recorded for the fully protonated species at $\mathrm{pH}=2.60$, the presence of small amounts of J-aggregate (even at very low concentrations, $10^{-7} \mathrm{M}$ ) precluded a completely unambiguous spectrophotometric determination (see the electronic Supplementary Materials).

The homoassociation tendency of the fully protonated forms of the amphiphilic porphyrins can be conveniently studied by recording their UV-Vis spectra in solutions of increasing concentration under comparable conditions of aqueous $\mathrm{HCl} 0.1 \mathrm{M}$ (see the electronic Supplementary Materials). The presence of aggregation is monitored through the appearance of a red-shifted J-aggregate band, compared to that of the deprotonated monomer [32-34]. Comparing the critical aggregation concentrations of the acidic forms of $8\left(3.78 \times 10^{-5} \mathrm{M}\right)$ and of $\mathbf{1 3}\left(1.75 \times 10^{-6} \mathrm{M}\right)$ to those of $\mathbf{1}\left(9.28 \times 10^{-7} \mathrm{M}\right)$ and of 2 $\left(7.50 \times 10^{-6} \mathrm{M}\right)$ [14], in the same $\mathrm{HCl} 0.1 \mathrm{M}$ media, that of 8 is between one and two orders of magnitude greater than those of the three others, which are much more similar among them. This result indicates an appreciable destabilization of the J-aggregate of $\mathbf{8}$, probably due to the fact that the conformational mobility of the (2-pyrrolidinyl)methyl substituent at the 5-meso position hinders the packing of the monomer units. Nonetheless, the concentration of the porphyrin needed for catalysis (typically $10^{-2} \mathrm{M}$ ) is still about three orders of magnitude higher than the critical aggregation of the protonated hybrid $\mathbf{8}$, assuring in this way that the catalyst can be conveniently deactivated by the acid-induced flocculation of the porphyrin.

We next turned our attention to the catalytic activity of the chiral amphiphilic porphyrins 8 and 13, taking as a benchmark reaction the well-known [17,35-38] aldol addition of cyclohexanone 14 to 4-nitrobenzaldehyde 15 (Scheme 6 and Table 1). For comparison purposes, some of the results previously obtained with the achiral porphyrins 1 and 2 [14] are included in Table 1.

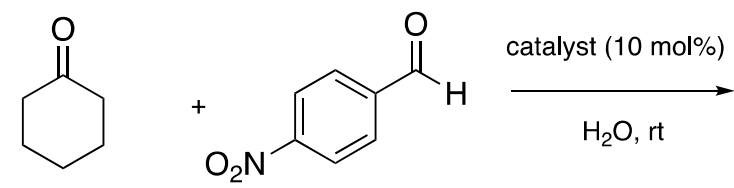

14 (5 mol equiv) $\quad 15$ ( 1 mol equiv)<smiles></smiles>

16a (anti)<smiles></smiles>

16b (syn)

Scheme 6. Aqueous aldol reaction of cyclohexanone 14 with 4-nitrobenzaldehyde 15. 
Table 1. Catalysis of the aqueous aldol reaction of cyclohexanone with 4-nitrobenzaldehyde ${ }^{\text {a }}$.

\begin{tabular}{ccccc}
\hline Entry & Catalyst & Time & ${\mathbf{\% ~} \text { Yield }^{\mathbf{b}}(\mathbf{d r})^{\mathbf{c}}} \mathbf{\% ~ E e ~}^{\mathbf{d}}$ \\
\hline $1^{\mathrm{e}}$ & $\mathbf{1}$ & 2 days & $100(66: 34)$ & - \\
$2^{\mathrm{e}}$ & $\mathbf{2}$ & 1 day & $100(93: 7)$ & - \\
$3^{4}$ & $\mathbf{8}$ & 2 days & $96(63: 37)$ & $1.9(2 S) / 0$ \\
$4^{\mathrm{f}}$ & $\mathbf{1 3}$ & 5 days & $89(70 / 30)$ & $16.7(2 S) / 11.8(2 S)$ \\
$5^{\mathrm{g}}$ & $\mathbf{1 3}$ & 7 days & $0(-)$ & - \\
$7^{\mathrm{h}}$ & $\mathbf{1 7}$ & 7 days & $52(66 / 34)$ & $34.2(2 S) / 26.7(2 S)$ \\
\hline
\end{tabular}

a $10 \mathrm{~mol} \%$ of the catalyst and $5 \mathrm{~mol}$ equiv. of cyclohexanone 14 (relative to 4-nitrobenzaldehyde 15 ) were used in all instances. ${ }^{b}$ Isolated yield of aldol $(\mathbf{1 6 a}+\mathbf{1 6 b})$ after chromatographic purification. ${ }^{\mathrm{c}} \mathbf{1 6 a} / \mathbf{1 6 b}$ ratio, determined by ${ }^{1} \mathrm{H}-\mathrm{NMR}\left(400 \mathrm{MHz}\right.$ ) of the reaction crude before chromatographic purification. ${ }^{\mathrm{d}}$ Determined by chiral HPLC for 16a (anti) and 16b (syn), respectively. ${ }^{\mathrm{e}}$ [14]. ${ }^{\mathrm{f}} \mathrm{pH} 4.00 .1 \mathrm{M} \mathrm{AcOH} / \mathrm{NaOAc}$ buffer solution. ${ }^{\mathrm{g}} \mathrm{pH} 6.70 .1 \mathrm{M}$ $\mathrm{AcOH} / \mathrm{NaOAc}$ buffer solution. ${ }^{\mathrm{h}} 10 \mathrm{~mol} \%$ of $p \mathrm{TsOH}$ was added to the reaction mixture.

A pH of 6.7 was measured for $0.1 \mathrm{M}$ aqueous solutions of the sodium salts of amphiphilic porphyrins $1,2,8$, and 13 , showing the absence of basic hydrolysis of the amine moieties. As seen in the third entry of Table 1, at this $\mathrm{pH}$, the disodium salt of 8 gave results, with respect to both yield and diastereoselectivity, similar to those of the achiral piperidine-porphyrin hybrid $\mathbf{1}$ (entry 1 ) for the aldol addition of cyclohexanone to 4-nitrobenzaldehyde: A 96\% yield after two days at rt, 63:37 anti (16a)/syn (16b) dr. The achiral isoindoline-porphyrin hybrid 2 (entry 2) showed an almost complete anti-diastereoselectivity. Chiral HPLC analysis of the aldol product mixture showed that the anti-isomer 16a was obtained with an almost negligible enantioselectivity $\left(1.9 \%\right.$ ee, favoring the "List-Houk" $\left(2 S, 1^{\prime} R\right)$ enantiomer). On the other hand, the syn diastereomer $\mathbf{1 6 b}$ was obtained in racemic form. The catalysis of this reaction by porphyrin 13 in water was somewhat less efficient (entry 4 in Table 1), since after 5 days at rt, some starting aldehyde was still observed, and the isolated yield of the aldol adducts (70:30 anti/syn dr) was $89 \%$. In this case, both diastereomers were obtained in optically active form, albeit with low enantioselectivity ( $16.7 \%$ ee for $\mathbf{1 6 a}, 11.8 \%$ ee for $\mathbf{1 6 b}$ ). In both compounds, the major enantiomer also had a (2S) absolute configuration. As expected, when the $\mathrm{pH}$ of the medium was lower than 4.3, both 8 and 13 were completely inactive due to the high insolubility of the aggregates, and at $\mathrm{pH} 4.0$ (entry 5 in Table 1), 13 gave no trace of product after a week of stirring at rt.

We also tested the catalytic ability of the chiral bicyclic pyrrolidine derivative $\mathbf{1 7}$ (the $\mathrm{N}$-deprotected form of 10, obtained in a 73\% yield as shown in Scheme 7). In a buffer solution of $\mathrm{pH}$ 6.7, 17 was clearly less active than the corresponding amphiphilic hybrid 13, since after 7 days at room temperature (rt), a 52\% yield of the aldol adducts 16a and 16b was isolated, with a similar anti/syn $\mathrm{dr}$ (entry 6 in Table 1). The ees for both adducts were, however, multiplied by at least a factor of two. The addition of one equivalent of $p$-toluenesulfonic acid (entry 7 in Table 1) resulted in a substantial lowering of the catalytic activity, although the enantioselectivity was further increased (60\% ee for $16 a, 32 \%$ ee for 16b). It is thus evident that the attachment of the sulfonated porphyrin moiety, although fostering the catalytic activity of the chiral amine unit in water, brings about an important diminution of the enantioselectivity. This strongly argues in favor of a true "in water" enamine mechanism for our amphiphilic porphyrin hybrids, since the less water-soluble ligand $\mathbf{1 7}$ most probably acts by micellar catalysis [20].

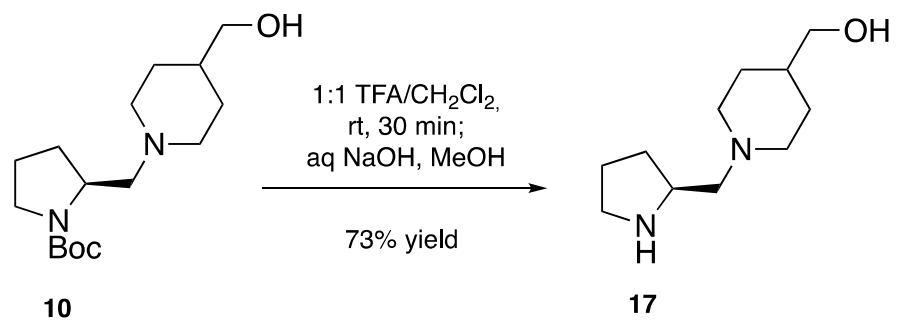

Scheme 7. Preparation of compound 17 
We examined next the aqueous aldol addition of acetone and 4-nitrobenzaldehyde, a reaction that is notoriously difficult to catalyze by small water-soluble organic molecules (Scheme 8) [16,39]. While both piperidine and isoindoline were able to catalyze this reaction, the piperidine-porphyrin hybrid 1 did not show any catalytic activity, in neutral conditions; on the other hand, the use of the isoindoline-derived porphyrin 2 allowed the reaction to proceed in an excellent yield, although 7 days were needed to achieve complete conversion (entries 1 and 2 in Table 2). We were pleased to find that both chiral amphiphilic porphyrins 8 and 13 were able to catalyze this reaction, although with null (entry 3 in Table 2) or very low (entry 4 in Table 2) enantioselectivities. Amino alcohol 17 showed a low catalytic activity (entry 5 in Table 2), with no enantioselectivity.<smiles>CC(=O)CC(O)c1ccc([N+](=O)[O-])cc1</smiles>

Scheme 8. Aqueous aldol reaction between acetone 18 and 4-nitrobenzaldehyde 15.

Table 2. Catalysis of the aqueous aldol reaction of acetone with 4-nitrobenzaldehyde ${ }^{\text {a }}$.

\begin{tabular}{ccccc}
\hline Entry & Catalyst & Time & \% Yield $^{\mathbf{b}}$ & $\mathbf{\% ~ E e ~}^{\mathbf{c}}$ \\
\hline $1^{\mathrm{d}}$ & $\mathbf{1}$ & 2 days & 0 & - \\
$2^{\mathrm{d}}$ & $\mathbf{2}$ & 7 days & 98 & - \\
3 & $\mathbf{8}$ & 4 days & 91 & 0 \\
$4^{\mathrm{e}}$ & $\mathbf{1 3}$ & 6 days & 98 & $6.2(R)$ \\
$5^{\mathrm{e}}$ & $\mathbf{1 7}$ & 7 days & 12 & 0 \\
\hline
\end{tabular}

a $10 \mathrm{~mol} \%$ of the catalyst and $5 \mathrm{~mol}$ equiv. of propanone 18 (relative to 4-nitrobenzaldehyde 15 ) were used in all instances. ${ }^{b}$ Isolated yield of aldol 19, after chromatographic purification. ${ }^{c}$ Determined by chiral HPLC. ${ }^{d}$ [14]. e $\mathrm{pH}$ 6.7 0.1 M AcOH/NaOAc buffer solution.

The enamine-mediated Michael addition of cyclohexanone 14 to 2-nitrostyrene 20 was also studied in aqueous media (Scheme 9), and the best results were obtained with hydrophobic or heterogeneous catalysts [19,40-45].

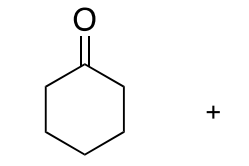

14 (5 mol equiv)<smiles>O=[N+]([O-])C=Cc1ccccc1</smiles>

20 (1 mol equiv)

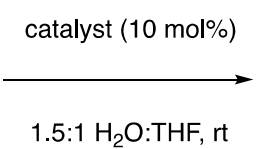

1.5:1 $\mathrm{H}_{2} \mathrm{O}: \mathrm{THF}, \mathrm{rt}$

21 (major syn isomer)

Scheme 9. Aqueous Michael addition of cyclohexanone 14 to 2-nitrostyrene 20.

We observed that addition of THF (tetrahydrofuran) to the aqueous solution in order to increase the solubility of 2-nitrostyrene in the reaction medium was necessary for the reaction. Under these conditions, only the isoindoline-derived porphyrin 2 showed a moderate catalytic activity, affording a 23\% yield of the Michael adduct 21 (in a 91:9 syn:anti diastereomeric ratio) after three days at rt (entry 2 in Table 3). When we examined the catalysis of this Michael addition with the chiral porphyrin hybrids, after seven days at $\mathrm{rt}$, no product was observed when $\mathbf{8}$ was used as a catalyst at neutral pH (entry 3 in Table 3). Some catalytic activity was observed with 13 (30\% yield after $40 \mathrm{~h}$ at rt, $18 \%$ ee of the major syn diastereomer, entry 4 in Table 3). It should be noted that $\mathbf{1 7}$ again proved to be a less efficient catalyst $(16 \%$ yield after $40 \mathrm{~h})$, although the syn adduct was obtained with a good enantioselectivity (75.6\% ee; entry 4 in Table 3$)$. 
Table 3. Catalysis of the aqueous Michael addition of cyclohexanone to 2-nitrostyrene ${ }^{\text {a }}$.

\begin{tabular}{ccccc}
\hline Entry & Catalyst & Time & $\mathbf{\% ~ Y i e l d ~}^{\mathbf{b}}(\mathbf{d r}){ }^{\mathbf{c}}$ & $\mathbf{\% ~ E e}^{\mathbf{d}}$ \\
\hline $1^{\mathrm{e}}$ & $\mathbf{1}$ & 3 days & $0(-)$ & - \\
$2^{\mathrm{e}}$ & $\mathbf{2}$ & 3 days & $23(91: 9)$ & - \\
3 & $\mathbf{8}$ & 7 days & $0(-)$ & - \\
$4^{\mathrm{f}}$ & $\mathbf{1 3}$ & 2 days & $30(93: 7)$ & $18\left(1^{\prime} R, 2 S\right)$ \\
$5^{\mathrm{f}}$ & $\mathbf{1 7}$ & 2 days & $16(95: 5)$ & $75.6\left(1^{\prime} R, 2 S\right)$ \\
\hline
\end{tabular}

a $10 \mathrm{~mol} \%$ of the catalyst and $5 \mathrm{~mol}$ equiv. of cyclohexanone 14 (relative to 2-nitrostyrene 20) were used in all instances. ${ }^{\mathrm{b}}$ Isolated yield of Michael adduct 21 (anti/syn mixture), after chromatographic purification. ${ }^{\mathrm{c}}$ Syn/anti ratio for 21, determined by ${ }^{1} \mathrm{H}-\mathrm{NMR}(400 \mathrm{MHz})$ of the reaction crude before chromatographic purification. ${ }^{\mathrm{d}}$ Determined by chiral HPLC for the major syn isomer of 21. ${ }^{\mathrm{e}}$ [14]. ${ }^{\mathrm{f}} \mathrm{A} \mathrm{pH}$ 6.7, $0.1 \mathrm{M} \mathrm{AcOH} / \mathrm{NaOAc}$ buffer solution was used instead of water.

Finally, it is worth noting that as previously described for their achiral analogs $\mathbf{1}$ and $\mathbf{2}$ [14], the chiral catalyst aggregates 8 and 13, after acidification of the reaction mixtures with concentrated aqueous $\mathrm{HCl}$, can readily be separated from the aldol or Michael adducts by centrifugation. The wet precipitates are carefully treated with solid sodium carbonate until a purple-colored solution, containing the trisodium salts of the porphyrin monomers, is obtained. This solution is then submitted to medium-pressure reverse-phase column chromatography. Using water as the mobile phase, inorganic salts are first eluted; increasing the gradients of methanol (from $0 \%$ to $50 \%$ ) results in the subsequent elution of the porphyrins in the protonation state corresponding to neutral $\mathrm{pH}$ (i.e., the disodium salt of 8 and the sodium salt of 13). Evaporation of the solvents under reduced pressure followed by lyophilization afforded the corresponding purple-colored solids, which are bench-stable for prolonged periods of time, in a ca. $80 \%$ yield.

In summary, we prepared two new chiral proline-derived amphiphilic 5-substituted-10,15,20tris(4-sulfonatophenyl) porphyrins, and their $\mathrm{pH}$-dependent supramolecular behavior was studied. In neutral aqueous solutions, the free-base anionic forms of the hybrids are highly soluble, allowing enamine-based organocatalysis to take place, whereas under acidic conditions, the porphyrinic protonated core of the hybrid leads to the formation of self-assembled structures, which are very insoluble in aqueous medium. The low degree of chirality transfer observed for aqueous Michael and aldol reactions strongly suggests that these reactions take place under true "in water" organocatalytic conditions. The precipitated J-aggregates can easily be separated from the reaction products by centrifugation of the acidified reaction crudes, and after neutralization and desalting, the anionic forms of the sulfonated amine-porphyrin hybrids, retaining their full catalytic activity, can be recovered in high yield.

\section{Materials and Methods}

\subsection{General Methods}

Commercially available reagents, catalysts, and solvents were used as received. Dichloromethane for porphyrin synthesis was distilled from $\mathrm{CaH}_{2}$ prior to use, and THF was dried by distillation from $\mathrm{LiAlH}_{4}$. Water of Millipore Q quality (18.2 MW.cm, obtained from Milli-Q1 Ultrapure Water Purification Systems, Millipore, Billerica, MA, USA) was used.

${ }^{1} \mathrm{H}(400 \mathrm{MHz})$ NMR spectra were recorded with a Varian Mercury 400 spectrometer. Chemical shifts $(\delta)$ are given in ppm relative to the peak of tetramethylsilane $(\delta=0.00 \mathrm{ppm})$; coupling constants $(J)$ are given in $\mathrm{Hz}$. The spectra were recorded at room temperature. Data are reported as follows: $\mathrm{s}$, singlet; $\mathrm{d}$, doublet; $\mathrm{t}$, triplet; $\mathrm{q}$, quartet; $\mathrm{m}$, multiplet; br, broad signal. IR spectra were obtained in a Nicolet 6700 FTIR instrument, using ATR techniques. UV-vis spectra were recorded on a double-beam Cary 500-scan spectrophotometer (Varian); cuvettes (quartz QS Suprasil, Hellma) cm were used for measuring the absorption spectra. The porphyrin solutions in water were carefully degassed by gentle bubbling a nitrogen gas stream prior to the spectrophotometric measurement. $\mathrm{pH}$ measurements were 
performed on a CRISON Micro pH $2000 \mathrm{pH}$-meter (Crison 52-04 glass electrode) at room temperature. The $\mathrm{pH}$-meter was calibrated prior to each measurement with buffers at $\mathrm{Ph}=7.00$ and 4.00 (Metrohm). Thin-layer chromatography was carried out on silica gel plates Merck $60 \mathrm{~F}_{254}$, and compounds were visualized by irradiation with UV light. Flash column chromatography was performed using silica gel Merck 60 (particle size: $0.040-0.063 \mathrm{~mm}$ ).

The HPLC analyses of the sulfonated porphyrins were performed on a Shimadzu high-performance liquid chromatograph equipped with two LC-10AS pumps, a Shimadzu CBM controller, an analytical precolumn Resolve C18 (Waters), and a Nucleosil 120-5C18 analytical column (250 mm $\times 4 \mathrm{~mm}$ ), using an elution gradient consisting of a mixture of methanol and tetrabutylammonium phosphate buffer $\left(3 \mathrm{mmol} \cdot \mathrm{L}^{-1} ; \mathrm{pH}=7.0\right)(1: 1 \mathrm{v}: \mathrm{v})$ to pure methanol over a period of $30 \mathrm{~min}$ at a flow rate of $0.6 \mathrm{~mL} \mathrm{~min}{ }^{-1}$ ( $\sim 2700-1050 \mathrm{psi})$. The elution profile was monitored at $\lambda=414 \mathrm{~nm}$ (UV-Vis detector SPD-6AV). Chiral HPLC analyses of aldol and Michael reaction products were performed on a Shimadzu instrument containing a LC-20-AD solvent delivery unit, a DGU-20AS degasser unit, and a SPD-M20A UV/VIS Photodiode Array detector, with chiral stationary phases $\left(250 \mathrm{~mm} \times 4.6 \mathrm{~mm}\right.$ Daicel Chiralpak ${ }^{\circledR}$ IC and $250 \mathrm{~mm} \times 4.6 \mathrm{~mm}$ Phenomenex ${ }^{\circledR}$ i-cellulose-5 columns; Phenomenex España, S.I., C. de Valgrande 8, Alcobendas, 28018, Madrid). All solvents were of HPLC grade and were carefully degassed prior to use. At time 0, the sample was injected.

$\mathrm{N}$-Boc-protected aminoaldehyde $\mathbf{1 0}$ was obtained according to the literature procedure [26].

\subsection{Spectrophotometric Titrations of the Porphyrins}

The $\left(\mathrm{pK}_{\mathrm{a} 1}+\mathrm{pK}_{\mathrm{a} 2}\right) / 2$ values of the diprotonated porphyrins were determined at room temperature with an error of \pm 0.02 units of $\mathrm{pK}_{\mathrm{a}}$ by monitoring the absorbance changes at a fixed wavelength (typically at an absorption maximum of one of the two species involved in the acid-base equilibrium) of micromolar solutions of the substance of an identical concentration of the porphyrin at different $\mathrm{pH}$ values, which were prepared by the addition of small volumes $(\sim 0.2 \mathrm{~mL})$ of a concentrated mother solution of the free-base porphyrin in water over solutions of acetic acid-sodium acetate buffers $(10 \mathrm{~mL})$ of a total concentration $0.1 \mathrm{M}$. All titrations were experimentally reproducible when repeated several times, preparing in each case new fresh solutions of all the reagents. The porphyrin solutions in water were carefully degassed by gentle bubbling of a nitrogen gas stream prior to the spectrophotometric titrations. The apparent $\mathrm{pK}_{\mathrm{a}}$ values were then obtained from the Henderson-Hasselbach equation by graphic interpolation using the following expression: $\left(\mathrm{pKa}_{1}+\mathrm{pKa}_{2}\right) / 2=\mathrm{pH}+\log ([$ diacid] $/[$ base $])$, where the ratio of acid to base in each solution was calculated, at a given wavelength, as: $[$ diacid $] /[$ base $]=\left(\mathrm{Abs}_{\text {base }}\right.$ $-\mathrm{Abs}) /\left(\mathrm{Abs}-\mathrm{Abs}_{\text {diacid }}\right)$. All spectra used in the $\mathrm{pK}_{\mathrm{a}}$ determinations showed accurate enough isosbestic points. The experimental numerical values and the regression plots for each porphyrin are presented in the electronic Supplementary Materials.

\subsection{Synthetic Procedures and Product Characterization}

\subsubsection{General Procedure for the Mixed Porphyrin Synthesis}

Dry dichloromethane ( $380 \mathrm{~mL} / \mathrm{mmol} \mathrm{N}$-Boc amino aldehyde) was introduced in a round-bottomed reaction flask equipped with magnetic stirring and a reflux condenser and purged for $15 \mathrm{~min}$ with nitrogen. The reaction flask was charged successively with the $N$-Boc amino aldehyde $(4,6$ or 11, 1.0 equiv.), freshly distilled benzaldehyde (3.0 equiv.) and with freshly distilled pyrrole (4.0 equiv.). The resulting solution was stirred for $5 \mathrm{~min}$ at $\mathrm{rt}$ and boron trifluoride etherate ( 0.40 equiv.) was added in one portion. Stirring was maintained for $3 \mathrm{H}$ under nitrogen, after protecting the reaction flask from direct contact with light. At this point, $p$-chloranil (3.0 equiv.) was added, and the reaction mixture was heated to reflux for $1 \mathrm{H}$ in open air. After cooling to $\mathrm{rt}$, most of the solvent was removed by rotary evaporation, taking care that the final volume was ca. $10 \mathrm{~mL} / \mathrm{mmol} \mathrm{N}$-Boc protected amino aldehyde. This residue was submitted to chromatographic purification on silica gel, eluting with dichloromethane. A fraction containing 5,10,15,20-tetraphenylporphyrin (TPP) eluted first, followed by a more polar 
fraction containing a mixture of the amino-substituted porphyrins. This fraction was submitted to a second chromatographic purification on silica gel, eluting with dichloromethane/methanol mixtures of increasing polarity. In this way, the target monosubstituted porphyrin was separated from the more functionalized porphyrins. Further purification can be achieved upon recrystallization from dichloromethane/hexane [15].

N-Boc-(S)-2-[(4-(hydroxymethyl)piperidin-1-yl)methyl]pyrrolidine (10). In a 50-mL round-bottomed flask, equipped with magnetic stirring, 4-(hydroxymethyl)piperidine 9 [26] (1.96 g, $17 \mathrm{mmol}$ ), $N$-Boc-(S)-prolinal 4 [22] (1.70 g, $8.5 \mathrm{mmol})$ and anhydrous methanol (15 mL) were added sequentially, and the solution was stirred at rt for $2 \mathrm{H}$ under nitrogen. Next, a preformed solution of sodium cyanoborohydride $(1.0 \mathrm{~g}, 8.5 \mathrm{mmol})$ and of anhydrous zinc dichloride $(1.16 \mathrm{~g}, 8.5 \mathrm{mmol})$ in anhydrous methanol $(15 \mathrm{~mL})$ was added with the aid of a cannula, and the resulting mixture was stirred under nitrogen for $48 \mathrm{~h}$ at rt. A $1 \mathrm{M}$ aqueous solution of $\mathrm{NaOH}(10 \mathrm{~mL})$ was added in one portion, and most of the methanol was distilled off in vacuo. The remaining aqueous solution was diluted with water $(20 \mathrm{~mL})$ and extracted thoroughly with ethyl acetate $(5 \times 20 \mathrm{~mL})$. The combined organic extracts were dried over sodium sulphate, and the solvent was stripped off by distillation under reduced pressure. The residue was purified by column chromatography (silica gel), eluting with 1:1 EtOAc/MeOH. In this way, the desired alcohol 10 (1.79 g, $6.0 \mathrm{mmol})$ was obtained as a yellowish oil (71\% yield).

${ }^{1} \mathrm{H}-\mathrm{NMR}\left(400 \mathrm{MHz} \mathrm{CDCI}_{3}, \mathrm{TMS}_{\text {int }}\right): \delta(\mathrm{ppm})=4.01-3.77(\mathrm{~m}, 1 \mathrm{H}), 3.49(\mathrm{~d}, \mathrm{~J}=6.3 \mathrm{~Hz}, 2 \mathrm{H}), 3.37-3.24(\mathrm{~m}$, 2H), 3.12-3.00 (m, 1H), 2.87-2.73 (m, 1H), 2.63-2.30 (m, 1H), 2.27-2.07 (m, 2H), 1.99-1.76 (m, 6H), 1.69 $(\mathrm{d}, J=11.4 \mathrm{~Hz}, 2 \mathrm{H}), 1.46(\mathrm{~s}, 9 \mathrm{H}), 1.36-1.14(\mathrm{~m}, 3 \mathrm{H}) .{ }^{13} \mathrm{C}-\mathrm{NMR}\left(100 \mathrm{MHz}, \mathrm{CDCl}_{3}\right): \delta(\mathrm{ppm})=154.68$, 68.11, 61.83, 55.34, 53.40, 46.72, 46.30, 38.71, 30.01, 29.17, 28.90, 28.70, 23.64, 22.78. HRMS (ESI $\left.{ }^{+}\right): \mathrm{m} / z$ calcd. for $\mathrm{MH}^{+}\left[\mathrm{C}_{16} \mathrm{H}_{31} \mathrm{~N}_{2} \mathrm{O}_{3}\right]=299.2329$, found 299.2331. $[\alpha]^{20} \mathrm{D}=-39.6\left(\mathrm{c}=0.71 ; \mathrm{CH}_{2} \mathrm{Cl}_{2}\right)$.

N-Boc-(S)-2-[(4-formylpiperidin-1-yl)methyl]pyrrolidine (11). To a cold $\left(-78^{\circ} \mathrm{C}\right)$ stirred solution of oxalyl chloride $(1.0 \mathrm{~mL}, 12 \mathrm{mmol})$ in dry dichloromethane $(4 \mathrm{~mL})$ under an Ar atmosphere, a solution of anhydrous DMSO $(0.8 \mathrm{~mL}, 12 \mathrm{mmol})$ was added via syringe. The resulting solution was stirred at $-78{ }^{\circ} \mathrm{C}$ for $30 \mathrm{~min}$, and after the addition of a solution of the alcohol 10 (1.79 $\left.\mathrm{g}, 6.0 \mathrm{mmol}\right)$ in dry dichloromethane $(8 \mathrm{~mL})$, stirring was maintained for $30 \mathrm{~min}$ at the same temperature. Triethylamine ( $3.3 \mathrm{~mL}, 24 \mathrm{mmol}$ ) was added dropwise, and the reaction mixture was stirred at $-78{ }^{\circ} \mathrm{C}$ during $4 \mathrm{H}$; after warming up to $\mathrm{rt}$, a $10 \% \mathrm{w} / \mathrm{w}$ aqueous solution of ammonium chloride $(20 \mathrm{~mL})$ was added in one portion. The phases were separated, and the aqueous one was extracted with dichloromethane $(3 \times 10 \mathrm{~mL})$. The combined organic phases were washed with aqueous-saturated sodium bicarbonate $(4 \times 20 \mathrm{~mL})$, dried over $\mathrm{Na}_{2} \mathrm{SO}_{4}$, and concentrated in vacuo to afford $1.56 \mathrm{~g}(5.3 \mathrm{mmol}, 88 \%$ yield $)$ of the aldehyde $\mathbf{1 1}$ as a yellowish oil.

${ }^{1} \mathrm{H}-\mathrm{NMR}\left(400 \mathrm{MHz}_{\mathrm{CDCl}}, \mathrm{TMS}_{\mathrm{int}}\right): \delta(\mathrm{ppm})=9.62(\mathrm{~s}, 1 \mathrm{H}), 3.97-3.73(\mathrm{~m}, 1 \mathrm{H}), 3.37-3.20(\mathrm{~m}, 2 \mathrm{H})$, 3.05-2.85 (m, 1H), 2.81-2.62 (m, 1H), 2.58-2.33 (m, 1H), 2.30-2.00 (m, 4H), 1.95-1.75 (m, 6H), 1.73-1.54 $(\mathrm{m}, 2 \mathrm{H}), 1.44$ (s, $9 \mathrm{H}) .{ }^{13} \mathrm{C}-\mathrm{NMR}\left(100 \mathrm{MHz} \mathrm{CDCl}_{3}\right): \delta(\mathrm{ppm})=204.12,154.64,61.51,55.31,54.39,52.72$, $48.12,46.29,29.86,28.68,25.78,25.61,23.61,22.76$. HRMS $\left(\mathrm{ESI}^{+}\right): \mathrm{m} / z$ calcd. for $\mathrm{MH}^{+}\left[\mathrm{C}_{16} \mathrm{H}_{29} \mathrm{~N}_{2} \mathrm{O}_{3}\right]=$ 297.2178, found 297.2176. $[\alpha]^{20}{ }_{\mathrm{D}}=-54.9\left(\mathrm{c}=0.55 ; \mathrm{CH}_{2} \mathrm{Cl}_{2}\right)$.

(S)-5-[(N-Boc-pyrrolidin-2-yl)methyl]-10,15,20-triphenylporphyrin (7). Obtained in a 10\% yield (0.17 g, $0.23 \mathrm{mmol})$ from $\mathrm{N}$-Boc-2-(S)-pyrrolidinethanal $6(0.50 \mathrm{~g}, 2.3 \mathrm{mmol})$ as a purple-colored solid. ${ }^{1} \mathrm{H}-\mathrm{NMR}$ $\left(400 \mathrm{MHz} \mathrm{CDCl}_{3}, \mathrm{TMS}_{\text {int }}\right): \delta(\mathrm{ppm})=9.92-9.59(\mathrm{~m}, 2 \mathrm{H}), 8.95(\mathrm{~d}, J=8.3 \mathrm{~Hz}, 2 \mathrm{H}), 8.81(\mathrm{~s}, 4 \mathrm{H}), 8.26-8.15$ $(\mathrm{m}, 6 \mathrm{H}), 7.83-7.70(\mathrm{~m}, 9 \mathrm{H}), 5.82-5.55(\mathrm{~m}, 1 \mathrm{H}), 5.08-4.96(\mathrm{~m}, 1 \mathrm{H}), 4.85-4.70(\mathrm{~m}, 1 \mathrm{H}), 2.35-2.15(\mathrm{~m}, 2 \mathrm{H})$, 1.95-1.71 (m, 2H), 1.67-1.53 (m, $9 \mathrm{H}), 1.48-1.33(\mathrm{~m}, 2 \mathrm{H}),-2.75$ (br, 2H). ${ }^{13} \mathrm{C}-\mathrm{NMR}\left(100 \mathrm{MHz}, \mathrm{CDCl}_{3}\right)$ : 143.09, 142.55, 142.49, 142.18, 142.09, 134.68, 132.93-130.54 (br, 4C), 127.78, 126.84, 126.74, 119.91, 119.84, $119.73,118.95,116.28,115.74,62.73,47.22,38.83,37.98,29.77,28.94,23.68,22.83$. FTIR (ATR): $v=$ $3318,2920,1655,1594,1465,1396,1163,880,700 \mathrm{~cm}^{-1}$. UV-vis $\left[\mathrm{CH}_{2} \mathrm{Cl}_{2}, \lambda_{\max } \mathrm{nm}\left(\varepsilon, \mathrm{L} \cdot \mathrm{mol}^{-1} \cdot \mathrm{cm}^{-1}\right)\right.$, $\left.3.43 \times 10^{-5} \mathrm{M}\right]: 417(400,000), 516(14,600), 551$ (7000), 591 (4500), 647 (3800). HRMS (ESI $\left.{ }^{+}\right): \mathrm{m} / z$ calcd. for $\mathrm{MH}^{+}\left[\mathrm{C}_{48} \mathrm{H}_{44} \mathrm{~N}_{5} \mathrm{O}_{2}\right]=722.3495$, found 722.3489 . 
(S)-5-[1-N-Boc-2-(methylpyrrolidinyl)piperidin-4-yl]-10,15,20-triphenylporphyrin (12). Obtained in 4\% yield (95 mg, $0.28 \mathrm{mmol}$ ) from N-Boc-(S)-2-[(4-formylpiperidin-1-yl)methyl]pyrrolidine 11 (0.89 g, $3.0 \mathrm{mmol})$ as a purple-colored solid. ${ }^{1} \mathrm{H}-\mathrm{NMR}\left(400 \mathrm{MHz}, \mathrm{CDCl}_{3}, \mathrm{TMS}_{\text {int }}\right): 9.75(\mathrm{~d}, J=4.6 \mathrm{~Hz}, 2 \mathrm{H}), 8.92(\mathrm{~d}$, $J=4.9 \mathrm{~Hz}, 2 \mathrm{H}), 8.81\left(\mathrm{dd}, J=12.7 \mathrm{~Hz}, J^{\prime}=4.8 \mathrm{~Hz}, 4 \mathrm{H}\right), 8.21\left(\mathrm{dd}, J=7.1 \mathrm{~Hz}, J^{\prime}=2.0 \mathrm{~Hz}, 6 \mathrm{H}\right), 7.86-7.67$ $(\mathrm{m}, 9 \mathrm{H}), 5.39(\mathrm{~m}, 1 \mathrm{H}), 4.23(\mathrm{~m}, 1 \mathrm{H}), 3.86-3.18(\mathrm{~m}, 5 \mathrm{H}), 2.78(\mathrm{~m}, 2 \mathrm{H}), 2.12(\mathrm{~m}, 4 \mathrm{H}), 1.62(\mathrm{~d}, J=11.1 \mathrm{~Hz}$, $9 \mathrm{H}), 1.01-0.75(\mathrm{~m}, 2 \mathrm{H}),-2.63$ (br, $2 \mathrm{H}) .{ }^{13} \mathrm{C}-\mathrm{NMR}\left(100 \mathrm{MHz}, \mathrm{CDCl}_{3}\right): 154.63,142.52,141.68,134.57$, 134.46, 131.97, 131.63, 131.50, 130.71, 128.15, 127.71, 126.79, 126.56,119.80, 119.64, 119.33, 61.79, 58.05, $55.66,54.41,47.48,46.35,44.82,38.00,36.45,31.93,30.06,29.65,28.60 . \mathrm{UV}$-vis $\left[\mathrm{CH}_{2} \mathrm{Cl}_{2}, \lambda_{\max } \mathrm{nm}(\varepsilon\right.$, $\left.\left.\mathrm{L} \cdot \mathrm{mol}^{-1} \cdot \mathrm{cm}^{-1}\right), 5.90 \times 10^{-5} \mathrm{M}\right]: 418$ (410,000), 516 (14,000), 549 (5900), 591 (3800), 647 (2600). HRMS $\left(\mathrm{ESI}^{+}\right): \mathrm{m} / z$ calcd. for $\mathrm{MH}^{+}\left[\mathrm{C}_{53} \mathrm{H}_{53} \mathrm{~N}_{6} \mathrm{O}_{2}\right]=805.4225$, found 805.4215.

\subsubsection{General Procedure for the Sulfonation/Deprotection of the Mixed Porphyrins}

In a round-bottomed flask, equipped with magnetic stirrer and a Dimroth reflux condenser capped with a calcium chloride tube, a stirred solution of the mixed porphyrin (1.0 mol equiv.) in concentrated $(96 \% \text { w/w })_{2} \mathrm{SO}_{4}\left(20 \mathrm{~mL} / \mathrm{mmol}\right.$ porphyrin) was heated to $100{ }^{\circ} \mathrm{C}$ for $6 \mathrm{H}$. After stirring for $18 \mathrm{~h}$ at $\mathrm{rt}$, water $\left(2 \mathrm{~mL} / \mathrm{mL} \mathrm{H}_{2} \mathrm{SO}_{4}\right)$ was carefully added dropwise and the resulting dark-green suspension was centrifuged at $6000 \mathrm{rpm}$ during $30 \mathrm{~min}$. The supernatant was decanted, and the remaining sulfuric acid was neutralized with solid $\mathrm{Na}_{2} \mathrm{CO}_{3}$ to afford a purple-colored solution. Inorganic salts were removed by medium-pressure reverse-phase column chromatography using MCI GEL CHP20P 75-150 $\mu \mathrm{m}$ (Diaion ${ }^{\circledR}$, Supelco/Sigma-Aldrich, Billerica, MA, USA), in which the porphyrin was slightly retained, thus allowing the elimination of inorganic salts using water as the eluent; increasing gradients of methanol (from $0 \%$ to 50\%) conveniently eluted the porphyrin. The concentration of the sample by evaporation of the solvents under reduced pressure followed by lyophilization afforded the sodium salt of the sulfonated porphyrin as a purple-colored solid [46].

(S)-5-(Pyrrolidin-1-ium-2-ylmethyl)-10,15,20-tris(4-sulfonatophenyl)porphyrin disodium salt 8. Obtained in $82 \%$ yield $(0.18 \mathrm{~g}, 0.19 \mathrm{mmol})$ from $(S)$-5-[(N-Boc-pyrrolidin-2-yl)methyl]-10,15,20-triphenylporphyirin $7(0.17 \mathrm{~g}, 0.23 \mathrm{mmol})$ as a purple-colored solid. ${ }^{1} \mathrm{H}-\mathrm{NMR}\left(400 \mathrm{MHz}, \mathrm{DMSO}-d_{6}, \mathrm{TMS}_{\text {int }}\right): \delta(\mathrm{ppm})=$ 9.94-9.85 (m, 2H), 8.99-8.91 (m, 2H), 8.86-8.76 (m, 4H), 8.26-8.12 (m, 6H), 8.11-8.00 (m, 6H), 5.62-5.52 $(\mathrm{m}, 2 \mathrm{H}), 5.47-5.35(\mathrm{~m}, 1 \mathrm{H}), 2.13-2.04(\mathrm{~m}, 2 \mathrm{H}), 1.87-1.76(\mathrm{~m}, 2 \mathrm{H}), 1.70-1.60(\mathrm{~m}, 2 \mathrm{H}),-2.96$ (br, 2H). Due to aggregation, only poorly resolved ${ }^{13} \mathrm{C}-\mathrm{NMR}$ spectra could be obtained for this compound. FTIR (ATR): $v=3426,1624,1392,1180,1122,1050,1011,736,632 \mathrm{~cm}^{-1}$. UV-vis $\left[\mathrm{H}_{2} \mathrm{O}, \lambda_{\max } \mathrm{nm}\left(\varepsilon, \mathrm{L} \cdot \mathrm{mol}^{-1} \cdot \mathrm{cm}^{-1}\right)\right.$, $\left.1.2510^{-6} \mathrm{M}\right]: 413$ (408,000), 517 (18,000), 554 (9200), 583 (8200), 634 (5200). HRMS (ESI $\left.{ }^{-}\right): \mathrm{m} / z$ calcd. for $\mathrm{M}^{3-}\left[\mathrm{C}_{43} \mathrm{H}_{32} \mathrm{~N}_{5} \mathrm{O}_{9} \mathrm{~S}_{3}\right]=286.0454(z=3)$, found 286.0455.

(S)-5-[1-(Pyrrolidin-1-ium-2-ylmethyl)piperidin-1-ium-4-yl]-10,15,20-tris(4-sulfonatophenyl)porphyrin sodium salt 13. Obtained in a $58 \%$ yield $(70 \mathrm{mg}, 0.07 \mathrm{mmol})$ from $(S)-5-[1-N-B o c-2-($ methylpyrrolidinyl)piperidin4-yl]-10,15,20-triphenylporphyrin $12(95 \mathrm{mg}, 0.12 \mathrm{mmol})$ as a purple-colored solid. No satisfactory NMR spectra could be obtained for this compound. UV-vis $\left[\mathrm{H}_{2} \mathrm{O}, \lambda_{\max } \mathrm{nm}\left(\varepsilon, \mathrm{L} \cdot \mathrm{mol}^{-1} \cdot \mathrm{cm}^{-1}\right), 5.90 \times 10^{-5} \mathrm{M}\right]$ : 413 (332,000), 521 (15,700), 559 (9500), 587 (7200), 646 (5100). HRMS (ESI $\left.{ }^{-}\right): \mathrm{m} / z$ calcd. for $\mathrm{M}^{3-}$ $\left[\mathrm{C}_{48} \mathrm{H}_{41} \mathrm{~N}_{6} \mathrm{O}_{9} \mathrm{~S}_{3}\right]=313.7371(z=3)$, found 313.7372 .

(S)-(1-(Pyrrolidin-2-ylmethyl)piperidin-4-yl)methanol (17). To a cold $\left(0{ }^{\circ} \mathrm{C}\right)$ stirred solution of N-Boc-(S)-2-[(4-(hydroxymethyl)piperidin-1-yl)methyl]pyrrolidine 10 (100 mg, $0.33 \mathrm{mmol})$ in dry dichloromethane $(5 \mathrm{~mL})$, trifluoroacetic acid $(5 \mathrm{~mL})$ was added dropwise, and the resulting mixture was stirred at rt for $30 \mathrm{~min}$. The volatiles were removed under vacuum, and the residue was diluted with methanol $(10 \mathrm{~mL})$. This process was repeated twice, and the residue was taken up in aqueous $1 \mathrm{M} \mathrm{NaOH}$ solution $(20 \mathrm{~mL})$. Extraction with ethyl acetate $(3 \times 10 \mathrm{~mL})$, drying over sodium sulphate, and elimination of the solvents by rotary evaporation afforded the desired product 17 (48 $\mathrm{mg}, 0.24 \mathrm{mmol}$, $73 \%$ yield) as a yellowish oil, which was used for the catalysis experiments without further purification. 
${ }^{1} \mathrm{H}-\mathrm{NMR}\left(400 \mathrm{MHz}, \mathrm{D}_{2} \mathrm{O}\right): \delta(\mathrm{ppm})=3.67-3.57(\mathrm{~m}, 1 \mathrm{H}), 3.47(\mathrm{~d}, J=6.5 \mathrm{~Hz}, 2 \mathrm{H}), 3.20-3.10(\mathrm{~m}, 2 \mathrm{H}), 3.01$ $\left(\mathrm{dd}, J=27.6 \mathrm{~Hz}, J^{\prime}=11.2 \mathrm{~Hz}, 2 \mathrm{H}\right), 2.64(\mathrm{~d}, J=6.1 \mathrm{~Hz}, 2 \mathrm{H}), 2.27-2.06(\mathrm{~m}, 3 \mathrm{H}), 2.02-1.83(\mathrm{~m}, 2 \mathrm{H}), 1.75(\mathrm{~d}$, $J=12.7 \mathrm{~Hz}, 2 \mathrm{H}), 1.64-1.51(\mathrm{~m}, 2 \mathrm{H}), 1.34(\mathrm{~d}, J=6.5 \mathrm{~Hz}, 2 \mathrm{H}), 1.31-1.16(\mathrm{~m}, 2 \mathrm{H}) . \mathrm{HRMS}\left(\mathrm{ESI}^{+}\right): \mathrm{m} / z$ calcd . for $\mathrm{MH}^{+}\left[\mathrm{C}_{11} \mathrm{H}_{23} \mathrm{~N}_{2} \mathrm{O}\right]=199.1805$, found 199.1802.

3.3.3. General Procedure for the Aqueous Organocatalysis of Aldol Reactions with the Amphiphilic Porphyrin-Amine Hybrids

A solution of the sulfonated amine-porphyrin hybrid $(0.01 \mathrm{mmol})$ in water (Milli-Q, $1 \mathrm{~mL})$ in a 10 - $\mathrm{mL}$ round-bottomed flask was stirred at $\mathrm{rt}$ for $2 \mathrm{~min}$; subsequently, the donor ketone $(0.50 \mathrm{mmol})$ and 4-nitrobenzaldehyde $(0.10 \mathrm{mmol})$ were added sequentially, and the resulting suspension was stirred (open air conditions) at rt until complete consumption of the aldehyde (TLC monitoring). After the addition of more water $(10 \mathrm{~mL})$, the reaction mixture was extracted with dichloromethane $(3 \times 10 \mathrm{~mL})$. The combined organic phase was dried over anhydrous $\mathrm{Na}_{2} \mathrm{SO}_{4}$, and after filtration, the organic solvent was eliminated in vacuo. Finally, the residue was purified by column chromatography in silica gel, eluting with 1:1 hexane/ethyl acetate [47].

2-(Hydroxy(4-nitrophenyl)methyl)cyclohexan-1-one (16a, anti $+\mathbf{1 6} \mathbf{b}$, syn) [48]. Yellow-colored solid. ${ }^{1} \mathrm{H}-\mathrm{NMR}\left(400 \mathrm{MHz}, \mathrm{CDCl}_{3}, \mathrm{TMS}_{\text {int }}\right): \delta(\mathrm{ppm})=8.25-8.18\left(\mathrm{~m}, 2 \mathrm{H}_{\text {anti }}, 2 \mathrm{H}_{\text {syn }}\right), 7.54-7.47\left(\mathrm{~m}, 2 \mathrm{H}_{\text {anti }}, 2 \mathrm{H}_{\text {syn }}\right)$, $5.49\left(\mathrm{t}, J=2.6 \mathrm{~Hz}, 1 \mathrm{H}_{\text {syn }}\right), 4.90\left(\mathrm{dd}, J=8.3 \mathrm{~Hz}, J^{\prime}=2.6 \mathrm{~Hz}, 1 \mathrm{H}_{\text {anti }}\right), 4.06\left(\mathrm{~d}, J=3.0 \mathrm{~Hz}, 1 \mathrm{H}_{\text {anti }}\right), 3.15(\mathrm{~d}$, $\left.J=3.0 \mathrm{~Hz}, 1 \mathrm{H}_{\text {syn }}\right), 2.67-2.31\left(\mathrm{~m}, 2 \mathrm{H}_{\text {anti }}, 2 \mathrm{H}_{\text {syn }}\right), 2.16-2.07\left(\mathrm{~m}, 1 \mathrm{H}_{\text {anti }}, 1 \mathrm{H}_{\text {syn }}\right), 1.90-1.32\left(\mathrm{~m}, 6 \mathrm{H}_{\text {anti }}, 6 \mathrm{H}_{\text {syn }}\right)$.

HPLC (Chiralpak@ IC, $1 \mathrm{~mL} \cdot \mathrm{min}^{-1}$, Hexane:IPA 95:5, $\left.\lambda=270 \mathrm{~nm}\right): \mathrm{t}_{\mathrm{R}}=\operatorname{syn}, 17.9 \mathrm{~min}\left(1^{\prime} R, 2 R\right)$, $19.6 \mathrm{~min}\left(1^{\prime} S, 2 S\right)$; anti, $22.4 \mathrm{~min}\left(1^{\prime} R, 2 S\right), 27.9 \mathrm{~min}\left(1^{\prime} S, 2 R\right)$.

4-Hydroxy-4-(4-nitrophenyl)butan-2-one (19) [16]. Yellow-colored solid. ${ }^{1} \mathrm{H}-\mathrm{NMR}$ (400 MHz, $\mathrm{CDCl}_{3}$, $\left.\mathrm{TMS}_{\text {int }}\right): \delta(\mathrm{ppm})=8.22(\mathrm{~d}, J=8.8 \mathrm{~Hz}, 2 \mathrm{H}), 7.54(\mathrm{~d}, J=8.7 \mathrm{~Hz}, 2 \mathrm{H}), 5.27\left(\mathrm{dd}, J=8.1 \mathrm{~Hz}, J^{\prime}=4.1 \mathrm{~Hz}, 1 \mathrm{H}\right)$, 3.55 (br s, 1H), 2.87-2.83 (m, 2H), $2.22(\mathrm{~s}, 3 \mathrm{H})$.

HPLC (Chiralpak@ IC, $1 \times 250 \mathrm{~mm} \times 4.6 \mathrm{~mm}, 1 \mathrm{~mL} \cdot \mathrm{min}^{-1}$, Hexane:IPA 95:5, $\lambda=270 \mathrm{~nm}$ ): $\mathrm{t}_{\mathrm{R}}=33.0 \mathrm{~min}(S), 35.4 \mathrm{~min}(R)$.

3.3.4. General Procedure for the Aqueous Organocatalysis of the Michael Addition of Cyclohexanone to 2-Nitrostyrene with the Amphiphilic Porphyrin-Amine Hybrids

A solution of the sulfonated amine-porphyrin hybrid $(0.01 \mathrm{mmol})$ in a 1.5:1 water/THF mixture $(0.20 \mathrm{~mL})$ in a $10-\mathrm{mL}$ round-bottomed flask was stirred at $\mathrm{rt}$ for $2 \mathrm{~min}$; subsequently, cyclohexanone 14 ( $49 \mathrm{mg}, 0.50 \mathrm{mmol}$ ) and 2-nitrostyrene $20(15 \mathrm{mg}, 0.10 \mathrm{mmol})$ were added sequentially, and the resulting suspension was stirred (open air conditions) at rt until complete consumption of the 2-nitrostyrene (TLC monitoring). After the addition of more water $(7 \mathrm{~mL})$, the reaction mixture was extracted with dichloromethane $(3 \times 10 \mathrm{~mL})$. The combined organic phase was dried over anhydrous $\mathrm{Na}_{2} \mathrm{SO}_{4}$, and after filtration, the organic solvent was eliminated in vacuo. Finally, the residue was purified by column chromatography in silica gel, eluting with 6:1 hexane/ethyl acetate.

$\left(1^{\prime} R^{*}, 2 S^{*}\right)$-2-(2-Nitro-1-phenylethyl)cyclohexan-1-one (21) [44]. Yellow-colored oil. ${ }^{1} \mathrm{H}-\mathrm{NMR}(400 \mathrm{MHz}$, $\left.\mathrm{CDCl}_{3}, \mathrm{TMS}_{\text {int }}\right): \delta(\mathrm{ppm})=7.36-7.23(\mathrm{~m}, 3 \mathrm{H}), 7.19-7.13(\mathrm{~m}, 2 \mathrm{H}), 4.94\left(\mathrm{dd}, J=12.5 \mathrm{~Hz}, J^{\prime}=4.5 \mathrm{~Hz}, 1 \mathrm{H}\right)$, $4.64\left(\mathrm{dd}, J=12.5 \mathrm{~Hz}, J^{\prime}=9.9 \mathrm{~Hz}, 1 \mathrm{H}\right), 3.76\left(\mathrm{td}, J=9.9 \mathrm{~Hz}, J^{\prime}=4.5 \mathrm{~Hz}, 1 \mathrm{H}_{\text {syn }}\right)^{*}, 2.74-2.64(\mathrm{~m}, 1 \mathrm{H}), 2.52$ - $2.33(\mathrm{~m}, 2 \mathrm{H}), 2.13-2.03(\mathrm{~m}, 1 \mathrm{H}), 1.83-1.57(\mathrm{~m}, 4 \mathrm{H}), 1.30-1.18(\mathrm{~m}, 1 \mathrm{H})$.

*The minor anti-isomer could be separated by chromatography and identified by its characteristic signal at $4.04-3.97\left(\mathrm{~m}, 1 \mathrm{H}_{\text {anti }}\right)$.

HPLC (Phenomenex i-cellulose-5, $1 \times 250 \mathrm{~mm} \times 4.6 \mathrm{~mm}, 1 \mathrm{~mL} \cdot \mathrm{min}^{-1}$, Hexane:IPA 90:10, $\lambda=220 \mathrm{~nm}$ ): ${ }_{s y n} \mathrm{t}_{\mathrm{R}}=37.8 \mathrm{~min}\left(1^{\prime} R\right)-2-(S), 41.8 \mathrm{~min}\left(1^{\prime} S\right)-2-(R)$.

Supplementary Materials: Chemical structures of the sulfonated porphyrins; HPLC chromatograms of the water-soluble sulfonated porphyrins; spectrophotometric determination of the $\mathrm{pK}_{\mathrm{a}}$ values of compounds 11 
and 16; effect of the porphyrin concentration on their aggregation behavior; ${ }^{1} \mathrm{H}$ and ${ }^{13} \mathrm{C}-\mathrm{NMR}$ spectra of new compounds; HPLC traces of Michael and aldol adducts.

Author Contributions: Conceptualization and methodology, A.M. and J.C.; investigation, A.A., P.T. and V.C.; writing-original draft preparation, A.M. and J.C.; writing—review and editing, A.M., A.A.; P.T. and J.C.; supervision, A.M. and J.C.; project administration, A.M.; funding acquisition, A.M. All authors have read and agreed to the published version of the manuscript.

Funding: This research was funded by FEDER, Ministerio de Ciencia, Innovación y Universidades, Agencia Estatal de Investigación, grant number CTQ2017-87864-C2-1-P.

Acknowledgments: A. Arlegui thanks the Ministerio de Ciencia, Innovación y Universidades for an FPI predoctoral fellowship. The administrative and technical support of the CCTiUB is gratefully acknowledged.

Conflicts of Interest: The authors declare no conflict of interest. The funders had no role in the design of the study; in the collection, analyses, or interpretation of data; in the writing of the manuscript, or in the decision to publish the results.

\section{References}

1. Blanco, V.; Leigh, D.A.; Marcos, V. Artificial switchable catalysts. Chem. Soc. Rev. 2015, 44, 5341-5370. [CrossRef]

2. Guler, M.O.; Stupp, S.I. A Self-Assembled Nanofiber Catalyst for Ester Hydrolysis. J. Am. Chem. Soc. 2007, 129, 12082-12083. [CrossRef]

3. Rodríguez-Llansola, F.; Escuder, B.; Miravet, J.F. Switchable Performance of an L-Proline-Derived Basic Catalyst Controlled by Supramolecular Gelation. J. Am. Chem. Soc. 2009, 131, 11478-11484. [CrossRef]

4. Zhang, C.; Xue, X.; Luo, Q.; Li, Y.; Yang, K.; Zhuang, X.; Jiang, Y.; Zhang, J.; Liu, J.; Zou, G.; et al. Self-Assembled Peptide Nanofibers Designed as Biological Enzymes for Catalyzing Ester Hydrolysis. ACS Nano 2014, 8, 11715-11723. [CrossRef]

5. Huerta, E.; van Genabeek, B.; Lamers, B.A.G.; Koenigs, M.M.E.; Meijer, E.W.; Palmans, A.R.A. Triggering Activity of Catalytic Rod-Like Supramolecular Polymers. Chem. Eur. J. 2015, 21, 3682-3690. [CrossRef]

6. Bohwmick, S.; Zhang, L.; Ouyang, G.; Liu, M. Self-Assembly of Amphiphilic Dipeptide with Homo- and Heterochiral Centers and Their Application in Asymmetric Aldol Reaction. ACS Omega 2018, 3, 8329-8336. [CrossRef]

7. Wei, Y.; Han, S.; Kim, J.; Soh, S.; Grzybowski, B.A. Photoswitchable Catalysis Mediated by Dynamic Aggregation of Nanoparticles. J. Am. Chem. Soc. 2010, 132, 11018-11019. [CrossRef]

8. Nojiri, A.; Kumagai, N.; Shibasaki, M. In situ manipulation of catalyst performance via the photocontrolled aggregation/dissociation state of the catalyst. Chem. Commun. 2013, 49, 4628-4630. [CrossRef]

9. Zhang, C.; Shafi, R.; Lampel, A.; MacPherson, D.; Pappas, C.G.; Narang, V.; Wang, T.; Maldarelli, C.; Uljin, R.V. Switchable Hydrolase Based on Reversible Formation of Supramolecular Catalytic Site Using a Self-Assembling Peptide. Angew. Chem. Int. Ed. 2017, 56, 14511-14515. [CrossRef]

10. Li, Y.; Caumes, X.; Raynal, M.; Bouteiller, L. Modulation of catalyst enantioselectivity through reversible assembly of supramolecular helices. Chem. Commun. 2019, 55, 2162-2165. [CrossRef]

11. Würthner, F.; Kaiser, T.E.; Saha-Möller, C.R. J-Aggregates: From Serendipitous Discovery to Supra- molecular Engineering of Functional Dye Materials. Angew. Chem. Int. Ed. 2011, 50, 3376-3410. [CrossRef] [PubMed]

12. Arlegui, A.; El-Hachemi, Z.; Crusats, J.; Moyano, A. 5-Phenyl-10,15,20-Tris(4-sulfonatophenyl)porphyrin: Synthesis, Catalysis, and Structural Studies. Molecules 2018, 23, 3363. [CrossRef] [PubMed]

13. Arlegui, A.; Soler, B.; Galindo, A.; Orteaga, O.; Canillas, A.; Ribó, J.M.; El-Hachemi, Z.; Crusats, J.; Moyano, A. Spontaneous mirror-symmetry breaking coupled to top-bottom chirality transfer: From porphyrin self-assembly to scalemic Diels-Alder adducts. Chem. Commun. 2019, 55, 12219-12222. [CrossRef] [PubMed]

14. Arlegui, A.; Torres, P.; Cuesta, V.; Crusats, J.; Moyano, A. A pH-Switchable Aqueous Organocatalysis with Amphiphilic Secondary Amine-Porphyrin Hybrids. Eur. J. Org. Chem. 2020, 4399-4407. [CrossRef]

15. Lindsey, J.S. Synthesis of meso-Substituted Porphyrins. In The Porphyrin Handbook; Kadish, K.M., Smith, K.M., Guilard, R., Eds.; Academic Press: San Diego, CA, USA, 2000; Volume 1, pp. 45-118.

16. Sakhtivel, K.; Notz, W.; Bui, T.; Barbas, C.F., III. Amino Acid Catalyzed Direct Asymmetric Aldol reactions: A Bioorganic Approach to Catalytic Asymmetric Carbon-Carbon Bond-Forming Reactions. J. Am. Chem. Soc. 2001, 123, 5260-5267. [CrossRef] 
17. Mase, N.; Nakai, Y.; Ohara, N.; Yoda, H.; Takabe, K.; Tanaka, F.; Barbas, C.F., III. Organocatalytic Direct Asymmetric Aldol Reactions in Water. J. Am. Chem. Soc. 2006, 128, 734-735. [CrossRef]

18. Hayashi, Y.; Sumiya, T.; Takahashi, J.; Gotoh, H.; Urushima, T.; Shoji, M. Highly Diastereo- and Enantioselective Direct Aldol Reactions in Water. Angew. Chem. Int. Ed. 2006, 45, 958-961. [CrossRef]

19. Mase, N.; Watanabe, K.; Yoda, H.; Takabe, K.; Tanaka, F.; Barbas, C.F., III. Organocatalytic Direct Michael Reactions of Ketones and Aldehydes with Beta-Nitrostyrene in Brine. J. Am. Chem. Soc. 2006, 128, 4966-4967. [CrossRef]

20. Brogan, A.P.; Dickerson, T.J.; Janda, K.D. Enamine-Based Aldol Organocatalysis in Water: Are They Really "All Wet"? Angew. Chem. Int. Ed. 2006, 45, 8100-8102. [CrossRef]

21. Jimeno, C. Water in asymmetric organocatalytic systems: A global perspective. Org. Biomol. Chem. 2016, 14, 6147-6164. [CrossRef]

22. Tang, Y.-Q.; Lu, J.-M.; Wang, X.-R.; Shao, L.-X. Palladium(II)-N-heterocyclic carbene complexes derived from proline: Synthesis and characterization. Tetrahedron 2010, 66, 7970-7974. [CrossRef]

23. Molander, G.A.; Romero, J.A.C. Investigations concerning the organolanthanide and group 3 metallocene-catalyzed cyclization-functionalization of nitrogen-containing dienes. Tetrahedron 2005, 61, 2631-2643. [CrossRef]

24. Bhat, C.; Tilve, S.G. Synthesis of (-)-hygrine, (-)-norhygrine, (-)-pseudohygroline and (-)-hygroline via Nef reaction. Tetrahedron Lett. 2011, 52, 6566-6568. [CrossRef]

25. Furuta, H.; Asano, T.; Ogawa, T. “N-Confused Porphyrin”: A New Isomer of Tetraphenylporphyrin. J. Am. Chem. Soc. 1994, 116, 767-768. [CrossRef]

26. Singh, R.; Panda, G. Prepared by the homologation of 4 as described in: L-Proline-derived nitrogenous steroidal systems: An asymmetric approach to 14-azasteroids. RSC Adv. 2013, 3, 19533-19544. [CrossRef]

27. Fernandes, I.A.; de Almeida, L.; Ferreira, P.E.; Marques, M.J.; Rocha, R.P.; Coelho, L.F.L.; Carvalho, D.T.; Viegas, C., Jr. Synthesis and biological evaluation of novel piperidine-benzodioxole derivatives designed as potential leishmanicidal drug candidates. Bioorg. Med. Chem. Lett. 2015, 25, 3346-3349. [CrossRef]

28. Jacobsen, J.L.; Berget, P.E.; Varela, M.C.; Vu, T.; Schore, N.E.; Martin, K.E.; Shelnutt, J.A.; Santos, L.M.; Medforth, C.J. Synthesis and nanostructures of 5,10,15,20-tetrakis(4-piperidyl)porphyrin. Tetrahedron 2013, 69, 10507-10515. [CrossRef]

29. Cabrer, A.; Ribó, J.M.; El-Hachemi, Z.; Crusats, J. 5,10,15,20-Tetrasulphonatophenyl regioisomers: How the location of the sulfonato groups determines the formation of their supramolecular aggregates. J. Porphyr. Phthalocyanines 2015, 19, 852-857. [CrossRef]

30. Zurita, A.; Duran, A.; Ribó, J.M.; El-Hachemi, Z.; Crusats, J. Hyperporphyrin effects extended into a J-aggregate supramolecular structure in water. RSC Adv. 2017, 7, 3353-3357. [CrossRef]

31. Cunderlikova, B.; Kaalhus, O.; Cunderlik, R.; Mateasik, A.; Moan, J.; Kongshaug, M. pH-Dependent modification of lipophilicity of porphyrin-type photosensitizers. Photochem. Photobiol. 2004, 79, 242-247. [CrossRef]

32. Ribó, J.M.; Crusats, J.; Farrera, J.A.; Valero, M.L. Aggregation in water solutions of tetrasodium deprotonated meso-tetrakis(4-sulfonatophenyl)porphyrin. J. Chem. Soc. Chem. Commun. 1994, 681-682. [CrossRef]

33. Fleischer, E.B.; Palmer, J.M.; Srivastava, T.S.; Chatterjee, A. Thermodynamic and Kinetic Properties of an Iron-Porphyrin System. J. Am. Chem. Soc. 1971, 93, 3162-3167. [CrossRef] [PubMed]

34. Pasternack, R.F.; Huber, P.R.; Boyd, P.; Engasser, G.; Francesconi, L.; Gibbs, E.; Fasella, P.; Venturo, G.C.; Hinds, L.D. Aggregation of meso-substituted water-soluble porphyrins. J. Am. Chem. Soc. 1972, 94, 4511-4517. [CrossRef] [PubMed]

35. Denmark, S.E.; Stavenger, R.A.; Wong, K.-T.; Su, X. Chiral Phosphoramide-Catalyzed Aldol Additions of Ketone Enolates. Preparative Aspects. J. Am. Chem. Soc. 1999, 121, 4982-4991. [CrossRef]

36. Yanasigawa, A.; Matsumoto, Y.; Asakawa, K.; Yamamoto, H. Asymmetric aldol reaction of enol trichloroacetate catalyzed by tin methoxide and BINAP·silver(I) complex. Tetrahedron 2002, 58, 8331-8339.

37. Kanemitsu, T.; Umehara, A.; Miyazaki, M.; Nagata, K.; Itoh, T. L-t-Leucine-Catalyzed Direct Asymmetric Aldol Reaction of Cyclic Ketones. Eur. J. Org. Chem. 2011, 2011, 993-997. [CrossRef]

38. Valero, G.; Moyano, A. Cooperative Effects Between Arginine and Glutamic Acid in the Amino Acid-Catalyzed Aldol Reaction. Chirality 2016, 28, 599-605. [CrossRef]

39. Chimni, S.; Mahajan, D. Small organic molecule catalyzed enantioselective direct aldol reaction in water. Tetrahedron Asymmetry 2006, 17, 2108-2119. [CrossRef] 
40. Zu, L.; Wang, J.; Li, H.; Wang, W. A Recyclable Fluorous (S)-Pyrrolidine Sulfonamide Promoted Direct, Highly Enantioselective Michael Addition of Ketones and Aldehydes to Nitroolefins in Water. Org. Lett. 2006, 8, 3077-3079. [CrossRef]

41. Luo, S.; Mi, X.; Liu, S.; Xu, H.; Cheng, J.-P. Surfactant-type asymmetric organocatalyst: Organocatalytic asymmetric Michael addition to nitrostyrenes in water. Chem. Commun. 2006, 42, 3687-3689. [CrossRef]

42. Vishnumaya; Singh, V.K. Highly Enantioselective Water-Compatible Organocatalyst for Michael Reaction of Ketones to Nitroolefins. Org. Lett. 2007, 9, 1117-1119. [CrossRef] [PubMed]

43. Alza, E.; Cambeiro, X.C.; Jimeno, C.; Pericàs, M.A. Highly Enantioselective Michael Additions in Water Catalyzed by a PS-Supported Pyrrolidine. Org. Lett. 2007, 9, 3717-3720. [CrossRef] [PubMed]

44. Singh, S.; Chimni, S.S. Chiral amine catalyzed enantio- and diastereoselective Michael reaction in brine. Tetrahedron Asymmetry 2012, 23, 1068-1079. [CrossRef]

45. Mondal, A.; Bhowmick, K.C. The carbamate esters as organocatalysts in asymmetric Michael addition reactions in aqueous media: When pyrrolidine backbone surpasses 1,2-diaminocyclohexane. Arkivoc 2018, 320-331. [CrossRef]

46. Busby, C.A.; DiNello, R.K.; Dolphin, D. A Convenient Preparation of meso-Tetra(4-sulfonatophenyl)porphyrin. Can. J. Chem. 1975, 53, 1554-1555. [CrossRef]

47. Jiang, Z.; Liang, Z.; Wu, X.; Lu, Y. Asymmetric aldol reactions catalyzed by tryptophan in water. Chem. Commun. 2006, 42, 2801-2803. [CrossRef]

48. Ricci, A.; Bernardi, L.; Gioia, C.; Vierucci, S.; Robitzer, M.; Quignard, F. Chitosan aerogel: A recyclable, heterogeneous organocatalyst for the asymmetric direct aldol reaction in water. Chem. Commun. 2010, 46, 6288-6290. [CrossRef]

Sample Availability: Samples of the compounds $\mathbf{8}$ and $\mathbf{1 3}$ are available from the authors.

(C) 2020 by the authors. Licensee MDPI, Basel, Switzerland. This article is an open access article distributed under the terms and conditions of the Creative Commons Attribution (CC BY) license (http://creativecommons.org/licenses/by/4.0/). 